For the $50^{\text {th }}$ Anniversary Edition of Sociological Review, edited by Tom Osbourne, Nik Rose and Mike Savage (2008). (www.blackwellpublishing.com/journal)

\title{
The Dirty History of Feminism and Sociology: or the War of Conceptual Attrition
}

\section{Beverley Skeggs}

Stuart Hall once accused feminists of defecating on the table of cultural studies:

For cultural studies (in addition to many other theoretical projects), the intervention of feminism was specific and decisive. It was ruptural...As a thief in the night, it broke in, interrupted, made an unseemly noise, seized the time, crapped on the table of cultural studies. (Hall 1992:282)

It certainly sounds dirty.

This is only one of many things of which feminists have been accused. The struggle to gain legitimacy and space within Sociology was, just like Cultural Studies, intense, producing many casualties. And it is a struggle that continues with some very specific temporal, spatial, national and local manifestations, which makes it a difficult history to write as perspective is shaped by location, positioning, capitals, vision, interest, will to ignorance and power. The representation offered here is partial and indicative aiming to connect the conditions for writing, speaking, hearing and practice to political context. I pepper this mainly national 'history' with personal examples to explicate some of the wider social issues. For this is not just a story of inhabitation but of the inscription of what we can think of as 'the social'. For Deleuze and Guattari (1977) inscription cuts or scars bodies in the making of strata and behaviour, assembling them into composite forms, enabling articulation and disarticulation of libidinal energies. Inscription therefore produces the subject via various regimes of classification, representation and control of the body: gender is a powerful form of inscription, both challenged and constituted by feminism. As Bogard (1998) notes:

There are forms of social inscription that are exclusive, that separate bodies from what they are capable of doing, that demean their desire and distort their sense; and there are modes that are inclusive and connective, that liberate desire, destroy limits and draw 'positive lines of flight' or escape. (p. 58)

The mechanisms of gendered inscription produce bodies through classification, representation, discourse and iteration, but feminist modes of gendered inscription offer alternative ways of assembling bodies, offering lines of flight that can cut through power, block its operations, break out of limits and liberate desire. It is this struggle over how to re-inscribe gender that we see in the battle between feminism and sociology, both conceptually through the organisation of forms of knowledge and discourse and institutionally by creating spaces for the re-inscriptions.

Sara Delamont (2003) has written an extensive account of the development of feminist sociology in the US and the UK, where she attempts to demarcate feminist sociology from the sociology of women/and or gender, sociology from feminist perspectives in other disciplines, and where she outlines the male-stream of sociology. It is a story told from within, by one of the creators, one that I partially recognise, but a history before my time yet one that shaped my time. The story here is told from different spaces by an inheritor, who fought different battles in different 
ways, at different times. Delamont cites and questions whether one of the books I was involved in putting together, Transformations (2000), following on from a remarkably successful feminist conference, held in the Centre for Women's Studies, once housed in the Sociology Department at Lancaster, is actually a feminist sociology book? Or is it, she asks, a contribution to sociology? Questions never raised by the editors (two of whom were sociologists ${ }^{1}$ ) as we merrily developed what we considered to be cutting edge interventions in feminist theory without even glancing at sociology, yet clearly with a sociological inheritance.

Our lack of questioning is symptomatic of many feminists who are now firmly established in British Sociology, who in the 1980s and 90s fought their battles outside of sociology, with little care about it as a discipline - although mounting a challenge to some of its foundational theories. We re-entered sociology with different knowledge and agendas creating different inscriptions. A feminist battle was waged both inside and outside the discipline. The discipline, if defined by academic departments and the institutionalisation of knowledge, is a privileged setting (as Bourdieu (1988) describes) where bodies, inheritance and power are organised and reproduced, a guarded territory, a space that not everybody can enter. Yet what is interesting about sociology is how many of those from outside the discipline ended up making their home within it. Is this about sociology's paucity and its re-energising? A demographic employment pattern? A recognition that it had to keep up with the times? Did the internal troops draw on extra firing power? Or was it infiltration? Why did sociology become the home for feminism in the UK? Is it just a story of remarkable women? In trying to unearth this complicated history many of these aspects combine.

Without a doubt in most places feminism has inscribed sociology, cutting into its complacency and comfort zones, carving out new areas and challenging old ones. Very little of traditional understandings of gender remains unscathed from feminist critique, yet whether this critique has re-inscribed the discipline of sociology is a different matter. It has been a war of attrition, attention and citation, and one that continues. For it is not just institutional space but the concepts at the heart of what constitutes sociology that marks the battleground. The institutional spaces have been easier to inhabit than changing the foundational concepts. As Mary Evans (2003) reveals, Plato's 'natural' women and 'cultural' man informed educated debate uncritically for centuries. For no matter how many women enter the discipline, as Anne Witz and Barbara Marshall (2004) note, masculinity, and the male it inscribes, continues to operate as a core constitutive category of the social/cultural. For instance, when women appear in one of the founding fathers, Durkheim's texts, they do so as a disruption to the central categories of his analysis, and thus are made to disappear in order for him to re-establish and maintain the internal consistency of his theory (Lehmann 1994). Women, for Durkheim have entirely different experiences of the social world by virtue of their nature. For Weber, an imaginary landscape of modernity is animated by masculine forms of social action, what Bologh (1990) identifies as a 'no-women's land'. And for Simmel (1984)'The male sex is not merely superior in relation to the female but acquires the status of the generally human' ( $p$. 103). As Evans notes, Marx did not radically disrupt existing ideas about the 'natural' differences between men and women, but he did believe that capitalism, although not positive, offered new public opportunities for women. ${ }^{2}$ These gendered inscriptions instigate a founding tradition by which masculinity functions as a metaphor for modernity and humanity and by which reason is established with masculinity in opposition to nature as feminine: see Seidler (1994) Smith (1974) and many more.

This tradition is carried into the present via Beck and Giddens (amongst others). By continuing to present the particularity of masculine (raced and classed) experience 
as if universal, and by espousing epochal theory rather than situated knowledge, the tradition is able to continue. Thus the critique must continue precisely because gender situates and challenges the dichotomous categories that frame sociological thought and displace sociology's founding masculine problematic-modernity. As Witz and Marshall point out, sociological discourse constitutes one way of imagining the modern social therefore we need to consider the extent to which sociological texts still perform this cultural work in the present (Winders 1991). They insist:

Yet theory text after theory text begins with 'modernity' as a universalised and often reified entity. Those same texts might admit 'women', en masse, or 'feminism' as a critical voice, in small doses, but only in carefully contained ways that do little to disturb the ideal type of modernity (or even to reveal it as such) that frames them. There is certainly no indication that modernity, the central problematic of sociology, is a thoroughly gendered construction. (2004: 9)

As Delamont (2003) notes in her analysis of contemporary sociology and social theory textbooks: 'Despite 30 years of the feminist critiques of the orthodox history of the discipline, the recent accounts share with those written in the 1960s an adherence to a simplistic and uncritical all-male grand narrative' (p.159). It is this consistency - of modernity with masculinity - across time and space within sociology, but consistently critiqued by feminists that informs the debates about the current status of sociology.

Contemporary deliberations conceptualise sociology as either the Queen of Sciences a la Comte, or a parasite or scavenger living off crumbs leftover from other disciplines, as suggested by John Urry in 1981. John Scott (2005) proposes that Sociology is neither a Queen nor an ever-disappearing parasite, but is under threat from increasing fragmentation. Along with economic sociology and cultural studies, he identifies feminism as one of the threats to this potential fragmentary future. In 2005 John Urry returns to his argument to strongly counter the idea that there is a centre to Sociology, instead suggesting it is more a field or a network that draws on a range of intellectual developments with an increasing internationalisation. Instead of being a disappearing discipline it is increasingly de-differentiated, less a ghetto and more an expanding discipline 'getting now into unexpected places and doing unexpected things' (para 1.7).

Yet even in this growth and fragmentation, modernity still remains central, often as a structuring absence: the public and the social remain firmly attached to masculinity. This is why postmodernism represented only a slight shift in theoretical perspective, one which kept the modern as a central structuring absence (Alway 1995), and why 'new' theories of reflexive modernity only serve to reproduce the very categories they set out to destabilise, presenting a new field for gendered exclusion (Adkins 2004a). Adkins notes how in theories of reflexive modernity women are not excluded from the social field and sociality as in classical accounts (via nature) but instead tend to be excluded from the cultural field instead: 'hermeneutic or aesthetic reflexivity is overwhelmingly masculinist' (p.150).

There is still a considerable difference between those who see feminism as an interloper, a political/social movement that has little academic credibility, existing at the margins trying to exert pressure on the centre to those who think of it as a particularity, singularity or specialism ${ }^{3}$, either as a new topic, or new field, but easily demarcated; those who absent-mindedly reproduce inherited concepts of modernity intact, and those who perceive feminism to be constitutive of what we know as sociological knowledge. 
Hence the 'dirty history' or war of conceptual attrition takes place across a range of different spaces. But only in certain historical moments were women in place to mount challenges. An account of the relations between feminism and sociology cannot just be a history of ideas, not just representation, visualisation or classification but also the inscription of bodies in spaces.

Jennifer Platt (2007), a sociological feminist pioneer, notes how in 1960 there were only 54 total university teaching posts in sociology, rising to 384 in 1972 . The proportion of women remained well below half: $16 \%$ of the total in 1968 and still only $26 \%$ in 1997. Platt identifies different employment moments that contracted and expanded space with differential impacts. When the Universities expanded in the 1960 at a period of maximum recruitment, few women applied and were appointed. The early years (1980s) of Thatcherism generated retrenchment in sociology, with outright ideological attacks and closure of sociology departments by the then Education Minister, Keith Joseph. The Social Science Research Council (now ESRC) lost funding and postgraduate grants, so that the training of future sociologists shrank generating what is now know as the 'lost generation'. This basic political economy underwrites the potential for feminism to engage with sociology within the academy. Those that remained in sociology operated under threat of closure, from a position of insecurity, but from outside they were viewed as privileged.

These economic cutbacks not only had a significant impact on the populating of sociology, but led to a dispersal of feminist sociologists who were finishing PhDs. I, for instance, in 1984, when my PhD funding ran out found three part-time teaching jobs at Keele University and Crewe and Alsager College of Higher Education and South Cheshire College of Further Education. My teaching ranged from PGCE in Sociology to YTS caring courses. My Triumph Herald was my office. I then had a one-year research fellowship on an ESRC quantitative study of 'Educational Opportunity of 16 year old School Leavers'), then taught Youth and Community Studies (Crewe and Alsager Higher Education college) and at the Worker's Education Association, before landing a Sociology post in a Higher Education College in 1986 (Worcester) for three years, then another three years in an Education Department at York University (where I taught in Women's Studies as an 'extra', i.e. with no teaching compensation from my home department) before I was able to move into Women's Studies (at Lancaster, in Sociology, a position I considered to be an incredible privilege). Such a dispersed history was not uncommon, with people working in Adult Education, Police Education, Management and Business Schools and media departments in (the then) Polytechnics.

We were either lost or dispersed. But also fighting feminist battles elsewhere such as women's refuges, rape crisis centres, Greenham Common (1981) and supporting the Miner's strike in 1984. My house in Crewe (Cheshire) was a 'safe-house' for miners previously arrested on picket lines and under injunction to stay in their local (Yorkshire) areas but who continued to campaign. With the young women from my $\mathrm{PhD}$ ethnography and the four miners staying at the time we 'super-glued' the local pornography shop in protest against violence against women before going out to organise support funds and dance.

When recruitment resumed in the 1990s, Platt notes, women were prominent among the new recruits, and in the 2000s they have probably become the majority. Thus, concludes Platt, the cohort or generational structure of male and female groups has not been the same. And they have different structures of academic socialisation, for the time one enters academic sociology one's 'training' in reading certain authors and people and one's ways of doing sociology, influence how debates are entered, what 
is seen to be significant and how knowledge is made to count. I had a route through Marx, Weber and Durkheim, Althusser, Foucault (simultaneously) and a small dose of feminism, as an undergraduate, Gramsci, Hall, Bourdieu, Marxist feminism and cultural studies as a postgraduate. This Marxist/post-structural route was a mix of what was available and what I 'chose', resonating with my experience of history and politics. Other feminists took different routes. ${ }^{4}$

I will now attempt to chart two of the three different trajectories in the history between feminism and sociology: firstly, feminism in sociology and secondly, women's studies with a brief address to cultural studies. The ESRC's (2005, 4th edition) 'Postgraduate Training Guidelines' identify Sociology, Sociology: Cultural and Media Studies; and Sociology - Women [sic] and Gender Studies as forms of legitimate sociology.

\section{Feminism in sociology}

Many of the early challenges to sociology (in the UK and US) occurred as a result of the 'radical' politics of the 1960s. Political manifestos such as Shulumith Firestone's challenge to biological reproduction by pointing to the redundancy of men and Valerie Solnos' SCUM manifesto ('The Society for Cutting up Men') offered radical visions for the future, challenging the taken for grantedness of gender and heterosexuality. The British Sociological Association conference on 'Sexual Divisions' in 1974 was organised by women sociologists active in the women's movement. This was a radical gesture, Delamont (2003) suggests, because until 1975 one badge of excellence for a sociology department in the US was to be all male, and top departments did not give tenure to women. It was the iconic figure of Angela Davis, US sociologist, imprisoned Black Power feminist, who drew my interest to sociology and feminism. I had no idea what either were when I was at school in the 1970s but I liked the passion of the speech and the powerful glamorous challenge contained in her image. She provided and continued to provide with her comrades throughout the 80 s and 90 s a very different class/race image to those of Greenham Common and the earlier Oxford Women's Liberation demonstrations. ${ }^{5}$

When I entered the discipline, the second wave feminist pioneers in sociology had generated new topics and provided evidence for their significance: Following on from Betty Freidan's (1963) Feminine Mystique, Hannah Gavron (1968) provided a sociological account of the dilemmas of housebound mothers, developed further by Ann Oakley's (1974) study that demonstrated women spent on average 77 hours per week on housework, and detailed strong class differences in women's approach to cleaning and childcare. Olive Banks published feminist critiques of family planning (Banks and Banks 1965) and opened up the field of sociology of education in 1968 (Banks 1968/1976). Liz Stanley (2005), a pioneer herself in many areas of sociology, maintains that it was Dorothy Smith $(1974 ; 1987)$ who provided the most coherent attempt to construct a systematic and fully articulated feminist sociology, as "a project" in 'The Everyday World as Problematic'. Oakley and Juliet Mitchell's (1976) 'The Rights and Wrongs of Women' also opened out different disciplinary areas, demonstrating their potential for critique. Millman and Kanter (1975) also provided an alternative perspective and critique of traditional sociology. And Sheila Rowbotham (1977 ) outlined how for 300 years women had been hidden from history. Evans (2003) also points to the significance of feminists like Germaine Greer and Kate Millett who influenced sociology from different disciplinary and national spaces.

From the mid 1970s solid descriptive empirical work demonstrated important features of women's lives and the structuring power of gender. In particular the role of women in the family (a traditional area studied in sociology, and naturalised via Parsonian theory and modernity) was deconstructed, exposing the prior invisibility of women's 
care (Finch and Groves 1980; Finch and Groves 1983; Ungerson 1982; Ungerson 1987), the significance of emotional labour and domestic work, including state allocated 'private' responsibility (David 1980), motherhood (Lewis 1980; Wearing 1984) and child development came under scrutiny (Riley 1983). The organisation of food (Charles and Kerr 1986; 1980), money (Pahl 1985; Pahl 1990), the relationship between gender and class in the family (Hunt 1980), the role of the male breadwinner and biological reproduction in the sexual division of labour (Brenner and Ramas 1984) was unpacked. The tax and social security system was inspected and linked to heterosexual family formation (Land 1978; 1979; 1983) and patriarchy was presented and disputed as a concept (see Beechey (1977) and later developed (Walby 1986; Walby 1990). ${ }^{6}$ Connections between policy and sociology were taken seriously in an attempt to impact upon the government. And the family was revealed to be anti-social (Barrett and Mclntosh 1982).

The relationship between work and leisure was shown to be entirely different for women (Deem 1986); as was the educational experience (Deem 1981; Wolpe 1975), youth training (Wickham 1982). The establishment of rationality via the teaching of mathematics was exposed as a technology of masculine power (Walkerdine 1985; Walkerdine 1988) and science (Kelly 1975; 1981). Attacks on modernity and rationality as specific masculine practices were developed (de Groot 1989; Mendus and Rendall 1989). Levels of domestic violence and child abuse were revealed (quantitatively and qualitatively) to be so high that they could not be ignored (Barrett and McIntosh 1982; Hall 1984; Stanko 1985). Stalwart efforts demonstrated unquestionably that the private was increasingly public, and violent.

The ideological power of glamour (Sherratt 1983), romance (Hall 1984; Harrison 1978; Leonard 1980; McRobbie 1978; Walkerdine 1984), advertising (Williamson 1978), magazines (Winship 1978; 1983), television and soap operas (Brunsdon 1981; Hobson 1982) was exposed, and challenges to sub-cultural theory (McRobbie and Garber 1976) were mounted. Reality and representation were subject to scrutiny, in sociology from Terry Lovell (1980) and Annette Kuhn (1978) in film studies. Heterosexuality was revealed as a social imperative (Rich 1980), as a form of social control (Smart and Smart 1978), produced through specific childhood socialisation (Jackson 1982) and as fundamental to the organisation of capitalism (Rubin 1975). New ideas were generated about nexi of subjectivities (Henriques, et al. 1984).

Not only were women being written back into history they were shown to be making it (Dyhouse 1976), and gender was revealed to be a historically structuring force (Dyhouse 1977; Hall 1979; Humphries 1977). Capitalism was shown to rely on a sexual division of labour (e.g. through the 'Domestic Labour Debate' and Glucksmann's pioneering work on the total social division of labour). ${ }^{7}$ Gender was added into traditional sociological areas, such as work (Cockburn 1983; Pollert 1981; Pringle 1986/89; Westwood 1984). Imperialism came in for a substantive critique from black feminists, as did the ethnocentricism of feminism itself (Carby 1982; hooks 1981; Lorde 1984; Parmar 1982).

Feminists presented incontrovertible evidence that could not be ignored, evidence that also made its way into the media and eventually government policy. This process of evidencing through empirical work fulfilled the best criteria of qualitative research.

Feminist knowledge simultaneously 'added on' (visualised and represented new perspectives, generating new knowledge) and took apart (radical re-inscriptions, cutting into knowledge): Bourdieu, for instance, came in for early criticism from Madeleine Arnot (1979), Marxism, from Hartmann and Sargent (1981), Barrett 
(1982), Foucault from Valerie Walkerdine (1987) and Althusser (Alison Assiter (1987).

It was a heady time. New journals proliferated (m/f was launched in 1978) and publishing houses were established (The Women's Press, Virago) and feminists who straddled academia and journalism impacted upon the media (Germaine Greer and Bea Campbell and Mary Stott at The Guardian). Magazines Spare Rib and Women's Voice widened access to Black American feminists such as Audre Lorde and Angela Davis. Today it would be impossible to describe feminism within such a small space, as publishers catalogues attest, leading Judith Stacey (2000) to protest that it is now impossible to 'keep up'.

Almost all sociological methods were subject to scrutiny and re-inscribed by feminism, even quantitative methods. Feminist critique came from within sociology e.g. Stanley and Wise $(1979 ; 1983)$ and Chris Griffin (1981) in Cultural Studies. These were incredibly important interventions, when one thinks that one of the most significant studies of social mobility undertook research on men and women but only reported on the men, or when class was considered to be produced through a husband's occupation (Crompton (1980) and Stanworth (1987)). Part of the methodological attack was on sexism and positivism ${ }^{8}$ but also on the epistemological basis for knowledge: who can know, who inscribes, in whose interests? US feminists, Sandra Harding (1984) and Nancy Hartsock (1986) critiqued the myth of objectivity advocating instead a feminist standpoint. ${ }^{9}$

Relations of reciprocity and equalising power injected a moral tone into methodologies: only women could speak to/for women, etc., and the heightened value given to women's experience, often generated through pseudo-consciousnessraising methods developed from the women's movement, placed the emphasis on telling, pain and suffering. These debates frequently reduced experience to knowing and essentialised genders, assuming that women had gender-specific experiences and that men and researchers were powerful. Yet, importantly, they insisted on asking 'in whose interests?' inserting ethical debates about power and exploitation into the heart of knowledge production. ${ }^{10}$ Consistently methodology has been both scrutinised and developed by feminists from a variety of different theoretical positions. It is the recognition of the situatedness of knowledge production that has been key to the continual modification of methodology. If methodology is a theory of the research process then the politics (interests, values, what is at stake in knowledge) are made explicit though the use of the performative 'feminist research'.

It was not until much later that the important critiques to essentialism, identity and the 'wounded attachment' came from post-structuralism feminists, such as Joan Scott (1987) and Diane Fuss (1992). Yet we still see these moral prescriptions in methods books, and the emphasis on telling one's 'self' in the name of reflexivity have become problematic disciplinary 'truths' often adopted by men (see (1989).

It was, however, an exciting if precarious time to be an academic. I have citational anxieties about all the research I have inadvertently excluded; references are indicative, to the ones most vividly remembered. I also suspect that during the $80 \mathrm{~s}$ and 90s only a few feminists were interested in impacting upon sociology; rather they were excitedly talking, shouting and arguing with each other, demonstrated by the proliferation of networks that were established, the diversification that occurred and the development and independent establishment of women's studies. Feminism permeated the boundaries of most social science and humanities disciplines, generating thematic connection over issues of 'gender', 'race', 'domesticity' 'image', etc, enabling feminist to speak to each other and expand their perspectives on a 
specific topic. My emergent topic, 'respectability' for instance, was debated by historians, race theorists, literary and legal theorists. This was not just an exciting time but also one of animation exhaustion and exhilaration.

\section{Women's Studies}

Both a physical space and a virtual space of ideas, for a time Women's Studies glowed with energy. This energy was rhizomatic sending out tendrils into many different places: Stanley (2005) notes how the UK sociology professoriat is positively replete with former and present Directors of Women's Studies, editors of women's studies journals, teachers of women's studies courses and authors of women's studies textbooks. ${ }^{11}$ Yet the legacies from the women's movement of equality and justice, brought into the space were hard to square with individualised competition of academia. Again, I can only tell an inherited story. I entered a Women's Studies Centre after women in Sociology, English and History secured my post through hard budgetary work. In Lancaster we had 23 women and men teaching Women's Studies options from their own departments, some able to 'fit' these into their departmental culture, others under pressure not to provide such courses.

Paradoxically the expansion of Women's Studies was enabled by the opening out of higher education through the neo-liberal market of Thatcherism, the accompanying 'legitimation crisis' in the state restructuring of the public sector labour market, the welfare state and the education system more generally (see Adkins and Leonard (Adkins 2002; Skeggs 2002)). In the 1980s and 90s Women's Studies in the UK was located in a rapidly changing climate with very different demands from a variety of sources. Most staff had been fighting for some time to have feminism taken seriously, for feminist 'entitlements' (the basics of equality and justice), whilst the students had inherited a different form of 'entitlement culture' based on consumer rights or a more activist set of demands. But not only did different politics and entitlements meet in a cramped space, the previous proliferation and development of feminism via popular culture meant that the student entitlements brought into Women's Studies spaces were often specifically shaped: for instance we had a group of undergraduate 'eco radical separatist feminists' who 'knew' the type of education they required, leading to many struggles over the type of feminism that was taught. The individualism inherent in popular feminism also ${ }^{12}$ sat uncomfortably with activists or those who had been fighting for years within academia for collective labour and space. These struggles which l've outlined in depth elsewhere (1992), and are contained in different versions in the Women's Studies journals of the time (such as Women's Studies Quarterly, Women's Studies International Forum, The Women's Studies Newsletter), always took a moral tone: 'you should be/doing' named the imperative to righteousness that shaped the struggle.

In the early stages of Women's Studies we worked in and campaigned for refuges, rape crisis centres, supported multitudinous political campaigns and challenged and developed educational practice. But this all changed with the introduction of performance monitoring of higher education through the Research Assessment Exercise (RAE, first introduced in 2001). In the UK Women's Studies was "returned" to a sub-set of the RAE sociology panel, hence institutionalising the relationship. Without the energy, people, publications and students of Women's Studies, UK sociology would look a, what Stanley names as a 'shabbier tiger'. At Lancaster, for instance, the vital research energy of Women's Studies was mentioned in ten departmental returns (across the social sciences and the humanities). The RAE (paradoxically) gave Women's Studies (in some places) greater legitimacy as the phenomenal rate of publications was made apparent. Yet this also increased the individualism and competitive nature of Women's Studies, both through carrots (the 
prize and pride of having so many publications) and the shaming and blaming stick of letting colleagues down as productivity was collectivised though the 'total' rating of the department. ${ }^{13}$ The impact of the RAE was to decrease time spent on external political activities and increase time writing. I think this is when feminism in the academy became feminism of the academy. The politics of knowledge replaced other forms of politics and the activism that had defined a particular sort of feminism became detached from the practice of feminism in academia. ${ }^{14}$ The RAE also influenced the type of appointments made, developing as a form of subjectivity attached to personal performance: 'are they a $5^{\star}$ person? is a question that continues to be asked.

The impact of Women's Studies upon the academy generally, and across nations, is much greater and certainly not commensurate to the small numbers of women involved. The impact was generated by what I affectionately call 'driven maniacs', women so devoted to their political and academic work that they often became seriously ill as a result, only to recover and start all over again.

During this time, always to my astonishment, we never spoke about our work as a job, it was a vocation, or a political/moral project. Martyr behaviour, modelled on motherhood, or extreme labour display often shaped work interactions. In the name of a collective political project, productivity increased massively. I look back and wonder if we were the perfect workers for capital: accelerating productivity, rarely concerned about labour conditions. ${ }^{15}$

Not only did we consent to super if indirect exploitation, we also legitimated male power through some of our political critique. By defining patriarchy as an all encompassing universal system and by attributing all men with power over women, the theory become performative, it brought into effect that which it named. And the performative enactment of male power by men was read as real, rather than performative (or even a performance).

Some male sociologists were strongly supportive: at Lancaster John Urry and Nick Abercrombie were essential to the support of the enterprise. Elsewhere I know David Morgan, Mike Savage, John Scott, Gregor McLellan, Nik Rose, Paul Atkinson, Michael Keith, Les Back and Tim May. In British Sociology, Delamont (Skeggs 1995b; Skeggs 1998) also points to the significance of Ronnie Frankenburg, editor of the Sociological Review, who not only critiqued his own work early in the 1970s, (2003) that of community studies but also welcomed a dialogue with feminists. He also provided journal space for classic feminist papers such as Acker (1976) Dominelli (1981), Charles and Kerr (1986), Finch and Mason (1986) and Kay (1990), and the translation by Diane Leonard of Christine Delphy into English (1990). His dialogue and self-critique remains exceptional.

Comparing these men to the 'American silverbacks' described by Delamont (2003) who easily excluded women from sociology suggests that the situation may have improved. But even supportive men may remain impervious to the conceptual challenges - the attempts at re-inscription - made by feminism. Yet it would be rare, if not downright lazy and embarrassing, to read Sociology without feminist citations. Who hasn't heard of Judy Butler, who working on technology would dare not to mention Donna Haraway, and where would post-colonialism be without Gayatri Spivak? When they arrive to speak in London it's difficult to get a seat. ${ }^{16}$

Sadly we do have sociologists who are completely blind to the fact that women exist, and/or have value; they are aware that gender exists as they benefit from promoting its continued universalism, but manage to protect themselves against any of 
feminisms' difficult questions. As Delamont notes, her 30-year war of attrition is nowhere near won. She writes: 'There is a continuing need to harry malestream sociologists to take feminist perspectives seriously, to cite women, to read women's work, and to confess to previous sexist sins of omission and commission' ( $p$. ix). It is astonishing that $\mathrm{PhD}$ students can emerge impervious to the debates that have rocked their discipline for so long; an example, l'd argue of what Lacan's (Delphy 1979) describes as the 'will to ignorance': maybe if they ignore it, it will just go away. But what feminism has demonstrated is precisely its commitment to attrition, versatility and staying power.

And it is also worth noting that a great deal of male intellectual labour was and still is underpinned by women academic's equivalent of domestic or invisible labour (the pastoral support, the caring labour); Maureen McNeil, for instance, tirelessly conducted research, supervised PhD students who are now famous feminists, organised teaching and pastoral matters from 1980-1996 at CCCS but is mostly written out of the romanticised accounts of the Centre'. ${ }^{17}$

\section{Briefly, Cultural Studies}

In Cultural Studies the struggle was more acute because they were engaged already in a what at first was considered to be a shared political project (as opposed to an established discipline). Charlotte Brunsdon (1977) identifies the first phase of the clash between feminism and the emergent cultural studies, between 1973-4, then the critiques of ethnocentrism which began in the early 80s. Stuart Hall (1996) points to the difficulty of engaging with feminism, how he and his colleagues were behaving as 'good, transformed men' when feminism broke in and every single unsuspected resistance rose to the surface, reinserting 'fully installed patriarchal power' which believed it had disavowed itself (p.269). He identifies the theoretical work at CCCS as 'theoretical noise'. Noise accompanied by a great deal of bad feeling, argument, unstable anxieties and angry silences, precisely because something was at stake in Cultural Studies. The 'at stake' he identifies as an attempt to come to terms with the volatile political conditions of its own production, a type of Marxist political practice at the moment of a disintegration of an entire historical and political project (state communism). It was a project influenced by Marxist questions about power, global reach, the state, the history-making capacities of capital, class and exploitation. But a project interrupted by feminism and then later questions of race:

For cultural studies the intervention of feminism was specific and decisive. It was ruptural. It reorganised the field in quite concrete ways. First, the opening of the question of the personal as political in quite concrete ways, and its consequences for changing the object of studying cultural studies, was completely revolutionary in a theoretical and practical way. Second, the radical expansion of the notion of power, which had hitherto been developed within the framework of the notion of the public, the public domain, with the effect that we could not use the term power...in the same way. Third, the centrality of questions of gender and sexuality to the understanding of power itself. Fourth, the opening out of many of the question that we thought we had abolished around the dangerous area of the subjective and the subject, which lodged those questions at the centre of cultural studies as a theoretical practice. (p269)

So the ruptural intervention of feminism described by Hall at the beginning of this paper is a positive re-ordering of knowledge: feminists re-inscribe the object and subject of culture, re-imagine the workings of power and expose the mechanisms by which knowledge can be achieved. Just as they continue to do with the social, the empirical, the affective, the methodological. 


\section{Conclusion}

This paper exemplifies what (1992) describes as a 'motivated account' exposing the writer's investments and interests. How could it be otherwise if we take feminist epistemological imperatives seriously? Yet l've tried to broaden the particular into the political, visualising what is at stake. When the RAE becomes institutionalised as a form of subjectivity demanding the performance of intense labour that places work over and above anything else, we know that a certain form of inscription has worked, one that assembles, demeans and shapes bodies, desire, possibly also destroying sense. Now compounded by the Weberian prediction of rational bureaucratic control, identified by feminists as a central imperative to some forms of masculinity, has not only crept in through the back door but also structures almost every minute of our working lives. We are constantly audited by a self-replicating culture, imposed by those infatuated by the fantasy of measurement, control and domination (see Quality Asssurance Agency benchmarks (QAA), Research Assessment Exercise (REA), and Performance Indicators, and Strathern 1997 (Hemmings 2007) and Evans for brilliant critiques). And bizarrely those who implement these measures have conceptual knowledge of Weber and all the critiques of Western imperial knowledge. It's almost surreal as banal positivist masculinity attempts to measure feminist performance. Our location in the academy enables our working lives, hence our bodies, to be structured and judged through the institutionalisation of the desire for masculine rationality: bad inscription. But as feminists we see this practice for what it is: a desperate desire for power and control (or the institutionalisation of a masculine super ego, as suggested by feminist psychoanalysts). And we laugh.

When feminists entered sociology they brought new descriptions, empirical evidence, perspectives, theories and debates, challenged complacency, cut into power and refreshed ideas with passion. They worked with ideas in different ways: as diagnosis, as description, as evidence, for policy, as critique, as a call to political action, to legislate, always an attempt to 'speak truth to power'. All these techniques can both inscribe and undo. Their versatility does not easily map onto Bauman's (2004) typology of intellectual style; in fact the different ways knowledge has been put to use by feminists represents a challenge to traditional idea-typologies. Nor is feminism just about visualisations and representations, but also the re-assemblage of research practice and 'training' (of what it means to be a sociologist and to do sociology); a site of constant struggle. And as well as re-inscribing sociology feminists also create their own forms of inscription: see the citational genealogy mapped by Hemmings (2005).

Yet what has always been consistent is feminism's use of a sociological imagination (amongst others). In a stunning update to C. Wright Mills, Les Back (2007) suggests sociologists should search for the remarkable things that are otherwise un-remarked. This is what feminism continues to do, beginning with the unearthing of the 77 hours of housework a week undertaken by women, documenting the remarkable levels of violence women continue to endure and exposing the lack of prosecutions for rape.

Feminism has done many remarkable things in many different spaces. Lynn Segal (2007) bemoans the loss of the radical spirit of feminist politics ${ }^{18}$, as do many others. Yet Adkins (2000; 2003) argues that Segal's claimed 'loss of politics' is an example of a generational logic that presents itself as a form of failed reproduction, premised upon an assumption that knows what the proper objects of feminism should be. 
Unlike Segal, I think feminism is still magical. It now has many objects and subjects, often improper, operating across a range of sites: knowledge, practice, networks, rhizomes, generating and liberating desire, fitting itself into cramped spaces, making surprising interventions, expanding those spaces, connecting bodies. As I look around me (now in a Sociology department at Goldsmiths, London University) I see remarkable women doing remarkable things in unexpected ways in unexpected places. I'm surrounded by fourteen feminist scholars with a common focus on the study of how gendering is a structuring social process, of how things, objects and people are put together and taken apart. And if I look into other departments (especially Media and Communications) I see even more wonderful women. They address fundamental sociological issues such as the formation and status of the social, the cultural, science, the psychological and psychoanalytic, the individual and the self, the legal, the affective; they ask what is the political rather than assuming that they know, questioning also the nation, the state, the ethical, the medical. They continue to investigate empirically, generating evidence, interrogating categories, challenging traditional understandings, always questioning the formation of relationships. Critique of the epistemological, ontological and methodological underpinnings of knowledge is absolutely central to their work. They put to work, develop and critique different theorists: including Arendt, Marx, Lacan, Bourdieu, Raymond Williams, Whitehead, Badiou and Butler, all engaging with feminist theorists throughout their work.

Location in sociology does not limit conversations to the discipline, as in the early traditions of feminism we stretch disciplinary boundaries, speaking and hearing from others. 'Woman' as object may not always be a central concern but research consistently engages with feminism, developed politically, practically and theoretically to understand gendered (and many more) processes. And this is how the struggle continues.

Do we now look to Sociology? We possibly glance as we continue to carve, cut, create, connect and invigorate our ideas. This, then, is not a story of 'failed reproduction' but of extraordinary replication, one that moves into many spaces, often beyond objects, sometimes into subjects, frequently relationships, but always into the knowledge systems that produce them. It continues to be a dirty history (in Hall's terms) of de-and re-inscription, of de- and re-territorialisation, of a struggle over the politics of knowledge.

l'd like to express my gratitude to the anonymous reviewers of this article who offered sharp critique and reminded me of important things/people l'd almost forgotten.

References:

Acker, S. 1981 'No Woman's Land', Sociological Review 29(1): 65-88.

Adkins, L. 2002 'Reflexivity and the Politics of Qualitative Research: Who Speaks for Whom, Why, How and When?' in T. May (ed) Companion to Qualitative Research, London: Sage.

- 2004a 'Gender and the Post-structural Social', in B. L. Marshall and A. Witz (eds) Engendering the Social: Feminist Encounters with Sociological Theory, Maidenhead, Berkshire: Open University Press/McGraw-Hill Education.

- 2004b 'Passing on Feminism: From Consciousness to Reflexivity', European Journal of Women's Studies 11(4): 427-444.

Adkins, L. and Leonard, D. 1992 'From Academia to the Education Market Place', Women's Studies Quarterly 3/4: 28-37.

Ahmed, S., Kilby, J., Lury, C., McNeil, M. and Skeggs, B. (eds) 2000

Transformations: Thinking Through Feminism, London: Routledge. 
Alway, J. 1995 'The Trouble with Gender: Tales of the Still Missing Revolution in Sociological Theory', Sociological Theory 13(3): 209-28.

Arnot, M. 1979 'Cultural Reproduction: the Pedagogy of Sexuality', Screen Education 32/33: 141-153.

Assiter, A. 1987 Althusser and Feminism:A Re-reading of Althusser, London: Pluto. Back, L. 2007 The Art of Listening, Oxford: Berg.

Banks, J. A. and Banks, O. 1965 Feminism and Family Planning in Victorian England, Liverpool: Liverpool University Press.

Banks, O. 1968/1976 Sociology of Education, Batsford: London.

Barrett, M. 1982 Women's Oppression Today: Problems in Marxist Feminist Analysis, London: Verso/NLB.

- 1984 Introduction to Fredrich Engels, The Origin of the Family, Private Property and the State, London: Penguin.

Barrett, M. and McIntosh, M. 1982 The Anti-Social Family, London: Verso/NLB.

Beechey, V. 1977 'Some notes on Wage Labour in Capitalist Production', Capital and Class 3: 45-66.

Bogard, W. 1998 'Sense and Segmentarity: Some Markers of a DeleuzianGuattarian Sociology', Sociological Theory 16(1): 52-74.

Bologh, R. W. 1990 Love or Greatness: Max Weber and Masculine Thinking - A Feminist Inquiry, London: Unwin Hyman.

Bourdieu, P. 1988 Homo Academicus, Cambridge: Polity Press.

Brenner, J. and Ramas, M. 1984 'Rethinking Women's Oppression', New Left Review 144: 33-72.

Brunsdon, C. 1981 'Crossroads - Notes on a Soap Opera', Screen 22(4): 32-38.

- 1996 'A Thief in the Night: Stories of Feminism in the 1970s at CCCS', in D. Morley and K.-H. Chen (eds) Stuart Hall: Critical Dialogues in Cultural Studies, London: Routeldge.

Carby, H. 1982 'White Woman Listen! Black Feminism and the Boundaries of Sisterhood', in CCCS (ed) The Empire Strikes Back: Race and Racism in 70s Britain, London: Hutchinson.

Charles, N. and Kerr, M. 1986 'Food for Feminist Thought', Sociolocical Review 34(3): 416-37.

Cockburn, C. 1983 Brothers: Male Dominance and Technological Change, London: Pluto Press.

Crompton, R. and Mann, M. (eds) 1987 Gender and Stratification, Cambridge: Polity Press.

David, M. 1980 The State, the Family and Education, London: Routledge and Kegan Paul.

de Groot, J. 1989 "'Sex" and "Race" The Construction of Language and Image in the Nineteenth Century', in S. Mendus and J. Rendall (eds) Sexuality and Subordination, London: Routledge.

Deem, R. 1981 'State Policy and Ideology in the Education of Women: 1944-1980', British Journal of Sociology of Education 12(2): 131-44.

- 1986 All Work and No Play, Milton Keynes: Open Univeristy Press.

Delamont, S. 2003 Feminist Sociology, London: Sage.

Deleuze, G. and Guattari, F. 1977 Anti-Oedipus: Capitalism and Schizophrenia, New York: The Viking Press.

Delphy, C. 1979 'Sharing the Same Table: Consumption and the Family', Sociological Review Monograph 28: 214-231.

Dominelli, L. 1986 'The Power of the Powerless', Sociological Review 34(1): 65-92.

Dyhouse, C. 1976 'Social Darwinistic Ideas and the Development of Women's Education in England 1880-1920', History of Education 5(2): 41-58.

- 1977 'Good Wives and Little Mothers: Social Anxieties and the Schoolgirls' Curriculum 1890-1920', Oxford Review of Education 3(1): 21-35.

Evans, M. 2003 Gender and Social Theory, Buckingham: Open University Press. 
- 2004 Killing Thinking: the Death of the Universities, London: Continuum.

Finch, J. and Groves, D. 1980 'Community Care and the Family: A Case for Equal Opportunities' International Social Policy, Cambridge: Cambridge University Press.

- (eds) 1983 A Labour of Love, London: Routledge and Kegan Paul.

Finch, J. and Mason, J. 1990 'Divorce, Marriage and Family Obligation', Sociolocical Review 2: 219-46.

Frankenberg, R. 1976 'In the Production of their Lives: men (?)...Sex and Gender in British Community Studies', in D. L. Barker and S. Allen (eds) Sexual Divisions and Society, London: Tavistock.

Fuss, D. 1989 Essentially Speaking: Feminism, Nature and Difference, London:

Routledge.

Gavron, H. 1968 The Captive Wife: Conflicts of Housebound Mothers,

Harmondsworth: Penguin.

Glucksmann, M. 1999 Women Assemble: Women Workers and the New Industries in Interwar Britain.

Griffin, C. 1980 Feminist Ethnography, Birmingham: Stencilled paper, CCCS.

Hall, C. 1979 'The Early Formation of Victorian Domestic Ideology', in S. Burman

(ed) Fit Work for Women, London: Croom Helm.

Hall, R. E. 1984 Ask Any Woman: A London Inquiry into Rape and Sexual Assault, Bristol: Falling Wall Press.

Hall, S. 1992 'Cultural Studies and its Theoretical Legacies', in L. Grossberg and C. Nelson (eds) Cultural Studies, New York and London: Routledge.

Harding, S. 1986 The Science Question in Feminism, Milton Keynes: Open University Press.

- 1991 Whose Science? Whose Knowledge, Ithaca, NY: Cornell University Press.

Harrison, R. 1978 'Shirley: The Relations of Reproduction and the Ideology of

Romance', in W. s. S. G. CCCS (ed) Women Take Issue: Aspects of Women's

Subordination, London Hutchinson.

Hartmann, H. and Sargent, L. 1981 The Unhappy Marriage of Marxism and

Feminism, London: Pluto.

Hartsock, N. 1987 'The Feminist Standpoint: Developing the Ground for a

Specifically Feminist Historical Materialism', in S. Harding (ed) Feminism and

Methodology, Milton Keynes: Open University Press.

Hemmings, C. 2005 'Telling Feminist Stories', Feminist Theory 6(2): 115-139.

-2007 'What is a Feminist Theorist Responsible for?' Feminist Theory 8(1): 69-76.

Henriques, J., Hollway, E., Urwin, C., Venn, C. and Walkerdine, V. 1984

Changing the Subject: Psychology, Social Regulation and Subjectivity, London:

Methuen.

Hobson, D. 1982 Crossroads: the Drama of a Soap Opera, London: Methuen.

hooks, b. 1981 Ain't I a Woman: Black Women and Feminism Boston: South End

Press.

Humphries, J. 1977 'Class Struggle and the Persistence of the Working Class

Family', Cambridge Journal of Economics 1: 241-58.

Hunt, P. 1980 Gender and Class Consciousness, London: Macmillan.

Jackson, S. 1982 Childhood and Sexuality, Oxford: Blackwell.

Kay, H. 1990 'Constructing the Epistemological Gap', Sociological Review 38(2):

344-51.

Kelly, A. 1975 'The Fate of Women Scientists', Women Speaking 4(July).

- (ed) 1981 The Missing Half: Girls and Science Education, Manchester:

Manchester University Press.

Kuhn, A. 1978 'Ideology, Structure and Knowledge', Screen Education 28(Autumn).

Lacan, J. 1977 Ecrits: A Selection, London: Tavistock.

Land, H. 1978 'Sex Role Stereotyping in the Social Security and Income Tax

Systems', in M. J. Chetwynd and O. Hartnett (eds) The Sex Role System:

Psychological and Sociological Perspectives. 
- 1979 'The Boundaries between the State and the Family', Sociological Review Monograph 28: 141-159.

- 1983 'Family Fables', New Socialist May/June: 20-21.

Lehmann, J. M. 1994 Durkheim and Women, Lincoln: University of Nebraska Press.

Leonard, D. 1980 Sex and Generation: A Study of Courtship and Weddings, London:

Tavistock.

Lewis, J. 1980 The Politics of Motherhood, London: Croom Helm.

Lorde, A. 1984 Sister Outsider, Trumansberg, NY: Crossing Press.

Lovell, T. 1980 Pictures of Reality : Aesthetics, Politics, Pleasure, London: BFI.

McRobbie, A. 1978 'Working Class Girls and the Culture of Femininity', in W. S. G.

CCCS (ed) Women Take Issue: Aspects of Women's Subordination, London:

Hutchinson/CCCS.

McRobbie, A. and Garber, J. 1976 'Girls and Subcultures: An Exploration', in S. Hall and T. Jefferson (eds) Resistance through Rituals, London: Hutchinson.

Mendus, S. and Rendall, J. (eds) 1989 Sexuality and Subordination, London:

Routledge.

Millman, M. and Kanter, R. M. (eds) 1975 Another Voice: Feminist Perspectives on Social Life and Social Science, New York: Anchor Books.

Mitchell, J. and Oakley, O. (eds) 1976 The Rights and Wrongs of Women, Harmondsworth: Penguin.

Oakley, A. 1974 The Sociology of Housework, Oxford: Martin Robinson.

Pahl, J. (ed) 1985 Private Violence and Public Policy, London: Routledge.

- 1990 Money and Marriage, London: Macmillan.

Parmar, P. 1982 'Gender, Race and Class - Asian Women in Resistance', in CCCS

(ed) The Empire Strikes Back: Race and Racism in 70s Britain, London: Hutchinson.

Payne, G. 2007 'Social Divisions, Social Mobilities and Social Research', Sociology 41(5): 901-915.

Platt, J. 2007 'The Women's Movement and British Journal Articles, 1950-2004',

Sociology 41(5): 961-975.

Pollert, A. 1981 Girls, Wives and Factory Lives, London: Macmillan.

Pringle, R. 1986/89 Secretaries Talk: Sexuality, Power and Work, London: Verso.

Rich, A. 1980 'Compulsory Heterosexuality and Lesbian Existence', Signs 5(4): 63160.

Riley, D. 1983 War in the Nursery: Theories of the Child and the Mother, London: Virago.

Roberts, H. (ed) 1981 Doing Feminist Research, London: Routledge.

Roseneil, S. 1995 Disarming Patriarchy: Feminism and Political Action at Greenham, Buckingham: Open University.

Rowbotham, S. 1977 Hidden from History : 300 years of Women's Oppression and the Fight Against it London: Pluto Press.

Rubin, G. 1975 'The Traffic in women: Notes on the 'Political Economy" of Sex in R R Reiter (Ed) Toward an Anthropology of Women', New York Monthly Review Press: 157-210.

Scott, J. 2005 'Sociology and its Others: reflections on Disciplinary Specialisation and Fragmentation', Sociological Research Online 10(1):

http://www.socresonline.org.uk/10/1/scott.html.

Scott, J. W. 1992 'Experience', in J. Butler and J. Scott (eds) Feminists Theorise the Political, London: Routledge.

Segal, L. 2000 'Only Contradictions on Offer', Women: A Cultural Review 11(1-2): 19-36.

- 2003 'Lost Worlds: Political Memoirs of the Left in Britain', Radical Philosophy 121: 6-23.

Seidler, V. J. 1994 Unreasonable Men: Masculinity and Social Theory, London: Routledge.

Sherratt, N. 1983 'Girls, Jobs and Glamour', Feminist Review 15: 47-62. 
Simmel, G. 1984 'The Problem of the Sexes', in G. Oakes (ed) Georg Simmel: on

Women, Sexuality and Love, New Haven, CT: Yale University Press.

Skeggs, B. (ed) 1995a Feminist Cultural Theory: Process and Production, Manchester: Manchester University Press.

- 1995b 'Women's Studies in Britain in the 1990s. Entitlement Cultures and Institutional Constraints', Women's Studies International Forum 18(4): 475-485.

- 1998 'Metamorphosis: Becoming a Women's Studies Director', Women's Studies National Newsletter Feb.

- 2002 'Techniques for Telling the Reflexive Self', in T. May (ed) Qualitative research in Action, London: Sage.

Smart, C. and Smart, B. 1978 Women, Sexuality and Social Control, London: Routledge and Kegan Paul.

Smith, D. 1974 'Women's Perspective as a Radical Critique of Sociology', Sociological Quarterly 44: 7-13.

- 1987 The Everyday World as Problematic: A Feminist Sociology, Buckingham: Open University Press.

Stacey, J. 2000 'Is Academic Feminism an Oxymoron', Signs 25(4): 1189-1194.

Stanko, E. 1985 Intimate Intrusions: Women's Experience of Male Violence, London: Unwin Hyman.

Stanley, L. 2005 'A Child of Its Time:Hybridic Perspectives on Othering in Sociology', Sociological Research Online 10(3):

http://www.socresonline.org.uk/10/3/stanley.html.

Stanley, L. and Wise, S. 1979 'Feminist Research, Feminist Consciousness and Experience of Sexism', Women's Studies International Quarterly 2(4): 359-74.

- 1983 Breaking Out, London: Routledge.

Stanworth, M. 1984 'Women and Class Analysis: A Reply to Goldthorpe', Sociology 18(2): 153-71.

Strathern, M. 1997 "Improving Ratings': Audit in the British Univesity System', European Review 5(3): 305-21.

Stuart, A. 1990 'Feminism: Dead or Alive', in J. Rutherford (ed) Identity: Community, Culture, Difference, London: Lawrence and Wishart.

Ungerson, C. 1982 'Women and Caring: Skills, Tasks and Taboos' Paper presented to British Sociology Conference, Manchester, April.

- 1987 Policy is Personal: Sex, Gender and Informal Care, London: Tavistock.

Urry, J. 1981 'Sociology as a Parasite: Some Vices and Virtues', in P. Abrams, R.

Deem, J. Finch and P. Rock (eds) Practice and Progress: British Sociology, 1950-

1980, London: George Allen and Unwin.

- 2005 'Beyond the Science of 'Society", Sociological Research Online 10(2):

http://www.socresonline.org.uk/10/2/urry.html.

Walby, S. 1986 Patriarchy at Work, Cambridge: Polity.

- 1990 Theorising Patriarchy, Oxford: Blackwell.

Walkerdine, V. 1984 'Some Day my Prince will come', in A. McRobbie and M. Nava (eds) Gender and Generation, London: Macmillan.

- 1985 'Science and the Female Mind: The Burden of Proof', Psych-Critique 1(1).

- 1987 Surveillance, Subjectivity and Struggle: Lessons from Pedagogic and

Domestic Practices: Centre for Humanistic Studies: University of Minnesota.

- 1988 The Mastery of Reason: Cognitive Development and the Production of

Rationality, London: Routledge.

Wearing, B. 1984 The Ideology of Motherhood, Sydney: Allen and Unwin.

Westwood, S. 1984 All Day and Everyday: Factory and Family in the Making of

Women's Lives, London: Pluto.

Wickham, A. 1982 'The State and Training Programmes for Women', in E. Whitelegg (ed) The Changing Experience of Women, London: Open University Press.

Williamson, J. 1978 Decoding Advertisments, London: Marion Boyars. 
Winders, J. A. 1991 Gender, Theory and the Canon, Madison: University of Wisconsin Press.

Winship, J. 1978 'A Woman's World: Woman - an Ideologyof Femininity', in W. S. G. CCCS (ed) Women Take Issue: Aspects of Women's Subordination, London:

Hutchinson.

- 1983 '"Options - For the Way You Want to Live Now" or a Magazine for Superwoman', Theory, Culture and Society 1(3): 44-65.

Witz, A. and Marshall, B. L. 2004 'Introduction: Feminist Encounters with Sociological Theory', in B. L. Marshall and A. Witz (eds) Engendering the Social: Feminist Encounters with Sociological Theory, Maidenhead, Berkshire: Open University Press/McGraw Hill Education.

Wolpe, A. M. 1975 'The Official Ideology of Girls' Education', in M. Flude and J. Ahier (eds) Educabiltiy, Schools and Ideology, London: Croom Helm.

Young, A. 1990 Femininity in Dissent, London: Routledge.

\footnotetext{
${ }^{1}$ Myself and Celia Lury. Bizarrely we were the ones with the greatest volume of sociological capital (BAs and PhDs in Sociology) in a catholic sociology department where most of the famous male sociologists came from different disciplinary spaces such as geography, history, philosophy, PPE and political theory.

${ }_{2}^{2}$ Although Michelle Barrett Adkins, L. 2004b 'Passing on Feminism: From Consciousness to Reflexivity', European Journal of Women's Studies 11(4): 427-444. notes how Engels' 'The Origin of the Family, Private Property and the State', was codified into a blueprint for the emancipation of women.

${ }^{3}$ Barrett, M. 1984 Introduction to Fredrich Engels, The Origin of the Family, Private Property and the State, London: Penguin. argues that the discipline has fragmented into subdisciplines, 'producing a tendency to become constrained within a uni-dimensional perspective that formulates research questions and presents explanations primarily in terms of one's own topic of interest, rather than recognising the multi-dimensional complexity of social life' (p. 902). He suggests that the discipline has become over-focused and hyperspecialised.

${ }^{4}$ See Payne, G. 2007 'Social Divisions, Social Mobilities and Social Research', Sociology 41(5): 901-915., for a consideration of how these different routes inform feminist theory and methodological debates.

${ }^{5}$ See Skeggs, B. (ed) 1995a Feminist Cultural Theory: Process and Production, Manchester: Manchester University Press. And Young, A. 1990 Femininity in Dissent, London: Routledge. ${ }^{6}$ In 2008 Sylvia Walby was awarded and accepted an OBE (Order of the British Empire).

${ }^{7}$ Liz Stanley identifies Miriam Glucksmann one of the most ambitious sociologists working in the field currently with her attempt to develop her concept of the Total Social Organisation of Labour (TSOL) (See Roseneil, S. 1995 Disarming Patriarchy: Feminism and Political Action at Greenham, Buckingham: Open University. and the journal Gender, Work and Organization, established in 1994).

${ }^{8}$ Although in the early days of American sociology, quantitative methods were considered to be women's work because they were technical rather than innovative, repetitive and uninteresting. Only in the 1930 s when computing was introduced did its status as a method increase and was claimed as masculine (see Delamont 2003).

${ }^{9}$ She changed her mind, In Glucksmann, M. 1999 Women Assemble: Women Workers and the New Industries in Interwar Britain., she changed her mind.

${ }^{10}$ Both Weber and Marx had asked similar questions, but it was the unrelenting consistency of their critique of the gendering of sociological knowledge that makes them specifically feminist. Hartsock developed the feminist standpoint from Marx's 'standpoint of the proletariat'.

${ }^{11}$ From Lancaster Women's Studies alone - Celia Lury, Jackie Stacey and myself served time as Heads of Sociology Departments, Goldsmiths, Lancaster, Manchester respectively and Sarah Franklin at BIOS, LSE. Mary Evans was director of Women's Studies at Kent before she became head of sociology (see Evans for an account)
} 
${ }^{12}$ See Harding, S. 1991 Whose Science? Whose Knowledge, Ithaca, NY: Cornell University Press. And Stuart, A. 1990 'Feminism: Dead or Alive', in J. Rutherford (ed) Identity: Community, Culture, Difference, London: Lawrence and Wishart.

${ }^{13}$ Rosemary Mellor, a wonderful woman in the Sociology department at Manchester University, who had been ill for some time after an accident, committed suicide. In her suicide note she mentioned not wanting to 'let colleagues down' in the forthcoming RAE.

${ }^{14}$ The relationship between activism and knowledge shifts at different political moments, having both activist and knowledge moments, sometimes simultaneously (e.g. suffrage), often in separate spaces (e.g. theatre).

${ }^{15}$ I was surprised to find how few feminist lecturers were members of the AUT (university union). Notwithstanding the feminist critiques of union masculinism, this reveals an individualised disposition to one's own labour.

${ }^{16}$ But as Clare Hemmings Hemmings, C. 2005 'Telling Feminist Stories', Feminist Theory 6(2): 115-139. notes the star status attributed to these US post-structural feminists usually signals a specific trajectory that not only occludes other feminist histories but makes it appear as if progress has been made from a naïve essentialist unfashionable feminist politics to a sophisticated advanced non-esssentialist theory.

${ }_{17}$ She moved to Lancaster Women's Studies to be Director in 1996 (incorporated into Sociology in 2004) where she continues to toil.

${ }^{18}$ See Winship, J. 1983 "'Options - For the Way You Want to Live Now" or a Magazine for Superwoman', Theory, Culture and Society 1(3): 44-65. for an excellent account of how 